\title{
THE INFLUENCE Of CASHLESS PAYMENT USAGE AND PROTECTION AGAINST FINANCIAL INCLUSION IN MICRO AND SMALL ENTERPRISES IN KEDIRI
}

\author{
Merlin Lenniawati ${ }^{1}$, Njo Anastasia ${ }^{2}$ \\ 1,2 Finance and Investment Program \\ Faculty of Business and Economics, Petra Christian University \\ Jl. Siwalankerto 121-131, Surabaya \\ E-mail: ${ }^{1}$ d11170040@john.petra.ac.id; ${ }^{2}$ anas@petra.ac.id
}

\begin{abstract}
This study examines the effect of the use of cashless payment system and the protection of cashless payment users on financial inclusion in MSEs in Kediri. The sample used in this study amounted to 400 respondents. Data were collected using an online questionnaire via Google Form. The data analysis method used in this study is PLS. The analysis test results show that there is a significant effect of using the cashless payment system on financial inclusion in MSEs (Micro and Small Enterprises) Kediri.
\end{abstract}

Keywords: Usage of Cashless Payment, Digital Consumer Protect, Financial Inclusion.

\section{INTRODUCTION}

Financial Inclusion is the access that households and businesses have to use financial products and services effectively, according to the Consultative Group to Assist the Poor (OJK, 2017). In Indonesia, the level of financial inclusion is still low, and this is supported by the statement of the President of the Republic of Indonesia, Mr. Joko Widodo, who said that the level of financial inclusion in Indonesia has increased but is still low. The level of financial inclusion in Indonesia in 2016 was only $67.8 \%$, and in 2019 it increased by $8.39 \%$. Compared to neighboring countries, Indonesia still has a low level of financial inclusion.

According to World Bank (2018), financial inclusion is experiencing an increase globally, and its development is accelerated by the presence of electronic media and the internet. This is supported by the data released in the World Bank's Global Findex survey, which shows that financial inclusion rates increased significantly between 2014 and 2017 due to the influence of the cashless payment system. The data reveal that financial inclusion had risen from $23 \%$ in 2011 to $43 \%$ in 2017. The use of technology that can be used as a way of increasing financial inclusion is cashless payment methods, including payments using banking services (mobile banking ( $m$-banking), debit cards, credit cards, Automated Teller Machines (ATM) cards, and payment applications or better known as electronic money (Ovo, Go-pay, Dana, and ShopeePay).

In Indonesia, not all individuals and businesses can access financial institution services to meet their various needs. Financial institutions have several provisions so that individuals or companies can access financial institution services. In running a business, of course, the bigger the business, the easier it is to access financial institutions (Wahono \& Pertiwi, 2020). At the same time, it is still tricky for Micro and Small Enterprises (MSEs) to do so. Although micro-enterprises are known for being un-bankable, the Chairman of the Financial Services Authority (FSA) accelerated the financial access by forming a Team to Accelerate Access Local Finance (TPAKD) so that the public, especially in the micro sector that has not been touched by the formal financial services institution, can enjoy the ease in managing their finances (Pemkot Kediri, 2019.

In fact, in the East Java region, especially Kediri, there is a cashless payment application created by Bank Indonesia. Namely, QRIS, which appeared in August 2019, has included 100 micro, small and medium enterprises in the process and 100 traditional market traders (Setiono, 2020). On the other hand, payments through financial institutions, such as transfers, have often been made by MSEs to pay bills or purchase goods and services created. Restaurants also have used cashless 
based payment systems, such as Ovo, Go-pay, funds, and ShopeePay. The use of the cashless payment system is considered to support sales expansion, namely by utilizing online stores, facilitating payments, and minimizing the risk of counterfeit money. The advantage of having a cashless payment system is felt directly by one of the MSME owners in Kediri by saying that cashless payment system makes it easier to make transactions, because it is no longer needed to look for change (Rahayu, 2020).

With the rapid development of technology and the use of financial institutions through digital products, the cashless payment system has an excellent opportunity to encourage the growth of financial inclusion with a record of user convenience and the security of personal data. The user convenience is to provide space for users to make transactions quickly and safely. Cashless payment system with more security will result to the increasing number of users so the security of the cashless payment system has a role in increasing financial inclusion. The fact is that one of the bank's branches located in Kediri is affected by data theft (Rezkisari, 2018). Therefore, user security is an essential aspect of using cashless payment system cashless, which is expected to improve continuously to protect the security of user data.

East Java is one of the areas with the largest population, where the lifestyle of the people is undergoing a change that wants everything to be easy, fast, efficient, and has a consumptive behavior. The existence of technology provides answers to community needs and helps MSEs in developing their business. The emergence of a cashless payment system can make it easier for MSEs to make transactions that impact increasing financial inclusion. However, many have not used a payment system cashless and do not yet have a level of financial inclusion in the Kediri Regency area. They conducted this research on micro and small business actors in the Kediri Regency area because the explanation of the facts above is only in Kediri City. Still, in the Kediri Regency area, there are no described facts, so further research is needed.

\section{LITERATURE REVIEW}

\section{Financial Literacy}

According to the Financial Services Authority (OJK), literacy is the level of knowledge, skills, public trust regarding financial institutions and products and services described in the index measure parameters. In contrast, according to the National Strategy for Indonesian Financial Literacy (SNLKI), financial literacy is a process or an activity that can increase the knowledge, confidence, and skills of consumers or the broader community to manage finances better (Ardiansyah, 2020; Francisca \& Malelak, 2020).

\section{Financial Inclusion}

According to the Regulation of the Financial Services Authority (POJK) Number 76 / POJK.07 / 2016 concerning increasing financial literacy and inclusion in the financial services sector for consumers and the public, financial inclusion is the availability of access to various institutions, products, and services finance is by the needs and abilities of the community to improve welfare (Putri, 2020). While according to the World Bank (2018), financial inclusion means that individuals and businesses can access useful and affordable financial products and services to meet life's needs, such as delivering responsible and sustainable transactions.

\section{MSMES}

According to Law No. 20 of 2008 concerning Micro, Small and Medium Enterprises (MSMEs). It explains that MSMEs are business activities capable of expanding employment and providing broad economic services to the community and can play a role in equalization and increase in community income, encouraging economic growth and play a role in realizing national stability. MSMEs are one of the main pillars of the national economy that must obtain the primary opportunity, support, protection, and development as widely as possible as a form of firm siding 
with the people's economic business groups, without neglecting the role of Large Enterprises and Owned Enterprises. State (BUMN) (Minister of Law and Human Rights, 2008).

\section{Payment System}

The payment system is the primary key in making transactions (buying and selling). Payment systems are divided into two types, namely cash payment systems, and cashless payment systems. The most striking difference between the two types of payment systems lies in the instruments used. In the cash payment system, the tools used are currency in physical forms such as coins and banknotes. Meanwhile, the cashless payment system uses payment instruments in cards (debit, credit, ATM), electronic bank services, and electronic money (Rangga, 2020).

\section{Cashless Payment System}

The cashless payment system refers to an economic arrangement where goods and services are transacted using a cashless payment system via electronic transfer (Tee \& Ong, 2016). The cashless payment system can be divided into two parts: through banking services (debit card, credit card, ATM card, m-banking) and non-banking (Go-pay, Ovo, Shopeepay, Dana).

\section{Protection of Cashless payment System Users}

Financial literacy is a vital aspect for cashless payment system users, where consumer protection has a close relationship with the user's financial literacy level. Consumer Protection is protection for consumers, covering the behavior of financial service entrepreneurs (OJK, 2013).

\section{METHODOLOGY}

\section{Type of Research}

The type of research used is associative-quantitative research. According to Sugiyono (2017), associative research aims to determine the effect or relationship between two or more variables, while quantitative method is used for research with data in the form of numbers and can be analyzed using statistics. This study examines the effect of using the cashless payment system and the protection of users of the cashless payment system on the financial inclusion of MSEs in the Kediri Regency.

\section{Population and Sample}

The population used in this study was MSEs in Kediri Regency on a micro and small scale who had used the cashless payment system in their business activities. The sample selection was carried out by non-probability sampling and using accidental sampling.

\section{Data Collection Type and Methods}

The data used is primary data, namely direct data from the field (Sugiyono, 2019). Retrieval of research data in this study was carried out by using a questionnaire method. Questionnaires are distributed by visiting MSEs and MSEs who come to fill out questionnaires on the provided gadgets. The selection of the instrument Google Forms aims to direct respondents to answer all questions with the support of settings from Google Forms and facilitate data collection, which is limited by distance and time.

\section{Variables:}

1. Concept

Empirical indicators : Statements that measure financial inclusion related to access and use.

2. Concept

Financial inclusion

Use of a cashless payment system 
Empirical indicators: Statements that measure the use of a cashless payment system,

3. Concept namely the perception of user satisfaction and willingness to use it.

Empirical indicators: Of cashless payment system users. Statements measuring the protection of cashless payment system users are the provider's perception of maintaining the privacy and confidentiality of all user information, data, and transactions.

\section{Data Analysis}

The data analysis technique used in this research is to use Partial Least Square, which aims to partially determine the effect of the independent variables in the form of cashless payment systems and the protection of cashless payment system users against the dependent variable, which is financial inclusion.

Table 1. Descriptive Coding of Respondents

\begin{tabular}{|c|c|c|c|}
\hline \multirow{2}{*}{$\begin{array}{c}\text { No } \\
1\end{array}$} & Variable & \multicolumn{2}{|r|}{ Coding } \\
\hline & Background & $\begin{array}{c}\text { Using a non-cash payment } \\
\text { system } \\
\text { Income }\end{array}$ & $\begin{array}{l}1=\text { No } \\
2=\text { Yes } \\
1=\text { Less than IDR } 300,000,000 \\
2=\text { IDR } 300,000,000-\text { IDR } 2,500,000,000 \\
3=\text { More than IDR } 2,500.000 .000\end{array}$ \\
\hline 2 & Demographic factors & $\begin{array}{c}\text { Gender } \\
\text { Education level }\end{array}$ & $\begin{array}{l}1=\text { Male } \\
2=\text { Female } \\
1=\text { Elementary school graduate } \\
2=\text { Junior high school graduate } \\
3=\text { Senior high school graduate } \\
4=\text { Diploma } \\
5=\text { Graduate } \\
6=\text { Graduate graduate }\end{array}$ \\
\hline 3 & $\begin{array}{c}\text { Usage of Cashless Payment } \\
\text { Systems }\end{array}$ & $\begin{array}{l}\text { Intention to use and user } \\
\text { satisfaction }\end{array}$ & $\begin{array}{l}1=\text { Strongly Disagree (STS) } \\
2=\text { Disagree }(\text { TS })\end{array}$ \\
\hline 4 & Digital Consumer Protect & $\begin{array}{l}\text { Privacy and data } \\
\text { confidentiality }\end{array}$ & $\begin{array}{l}3=\text { Neutral }(\mathrm{N}) \\
4=\text { Agree }(\mathrm{S})\end{array}$ \\
\hline 5 & Financial Inclusion & Access and use & $5=$ Strongly Agree (SS) \\
\hline
\end{tabular}

\section{Constructing a Path Diagram}

Creating an inner model that shows the relationship between the independent, dependent, and mediating variables and creating an outer model. The latent variable is shown in circles, whereas the empirical indicator is depicted as a box. A single arrow represents the relationship between variables.

\section{Outer Model Evaluation}

Evaluation of the outer model aims to assess the validity and reliability of each indicator (Yamin \& Kurniawan, 2009), Outer model evaluation can be done by:

a. Convergent Validity

Convergent validity is used to measure whether each estimated indicator validly measures the dimensions of the concept being measured. The validity test can be seen from the loading factor value. Loading factor measurement scale that is greater than 0.5 are said to be good (Ghozali, 2014).

b. Discriminant Validity

Discriminant validity is the measurement used for indicator with latent variables. The validity test can be seen from the cross-loading value. Suppose the cross-loading value of the indicators belonging to a variable is greater than the cross-loading value of the indicators against other variables, in that case the indicator used is declared valid. 
c. Reliability Test

Reliability test is used to test the reliability of a construct to prove the accuracy, consistency, and appropriateness of instruments in measuring constructs. Reliability tests can use two methods, namely Cronbach's alpha and composite reliability. Cronbach's alpha is used to measure the lower limit of the reliability value of a construct. A construct can be reliable if the value of Cronbach's alpha is greater than 0.6. At the same time, composite reliability is used to measure the actual value of the reliability of a construct. The rule of thumb for alpha value or composite reliability must be greater than 0.7 , although a value of 0.6 is still acceptable.

\section{Inner Model Evaluation}

Inner model evaluation is done by looking at the R-squares of each endogenous latent variable. The value of $\mathrm{R}$-squares explains the effect of exogenous latent variables on endogenous latent variables. A greater R-squares value will be directly proportional to the impact of the independent variable on the dependent variable. Then, to measure the constructed model used Q-square predictive relevance. The $Q$-square measures the observed value generated by the model and its parameter estimation. If the $Q$-square value> 0 , it has a predictive relevance model and if the $Q$ square value $<0$, it lacks a predictive relevance model.

\section{ANALYSIS AND DISCUSSION}

\section{Overview of Research Objects}

The data in this study were obtained from the results of distributing questionnaires. The research respondents are MSEs in the Kediri Regency who have used the cashless payment system. The data in this study have two independent variables and one dependent variable. Independent variables include the use of cashless payment systems and protection of users of cashless payment systems. The dependent variable in this study is financial inclusion. In this study, a total of 400 UMK respondents were obtained.

\section{Data Analysis}

\section{Outer Model Evaluation}

\section{a) Convergent Validity}

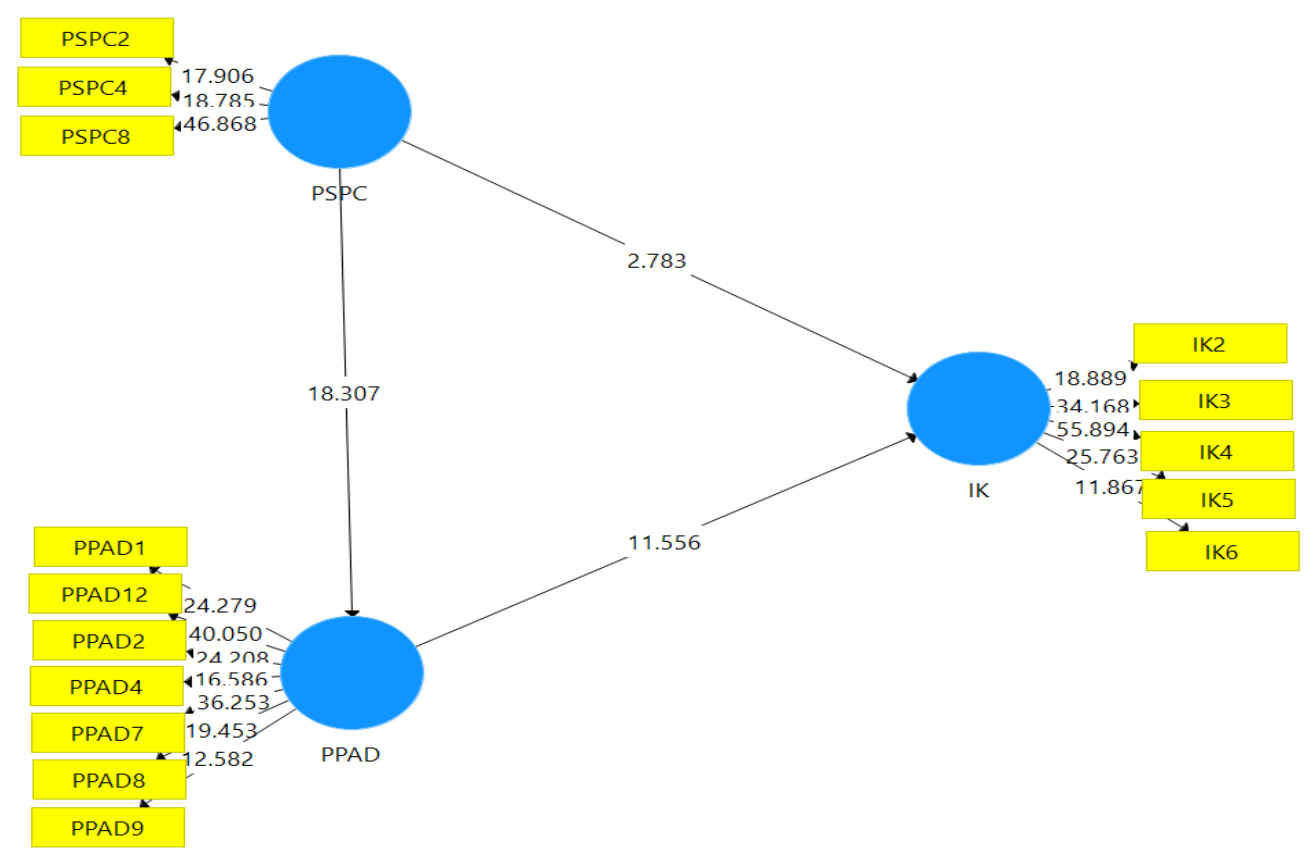

Figure 1. Path Analysis 
Table 2. Outer Model After Elimination

\begin{tabular}{|c|c|c|c|c|c|c|}
\hline \multirow{2}{*}{ Indicators } & \multicolumn{3}{|c|}{ SMEs } & \multicolumn{3}{|c|}{ Small Business } \\
\hline & IK & PPAD & PSPC & IK & PPAD & PSPC \\
\hline IK2 & 0.710 & & & 0.772 & & \\
\hline IK3 & 0.818 & & & 0.862 & & \\
\hline IK4 & 0.864 & & & 0.824 & & \\
\hline IK5 & 0.727 & & & 0.697 & & \\
\hline IK6 & 0.662 & & & 0.777 & & \\
\hline PPAD1 & & 0.732 & & & 0.688 & \\
\hline PPAD2 & & 0.728 & & & 0.691 & \\
\hline PPAD4 & & 0.651 & & & 0.742 & \\
\hline PPAD7 & & 0.790 & & & 0.740 & \\
\hline PPAD8 & & 0.656 & & & 0.700 & \\
\hline PPAD9 & & 0.610 & & & 0.630 & \\
\hline PPAD12 & & 0.791 & & & 0.681 & \\
\hline PSPC2 & & & 0.729 & & & 0.669 \\
\hline PSPC4 & & & 0.715 & & & 0.855 \\
\hline PSPC8 & & & 0.858 & & & 0.710 \\
\hline
\end{tabular}

The picture above shows that the value outer loading of all indicators meets the criteria (value outer loading $>0.5$ ).

\section{b) Discriminant Validity}

Table 3. Discriminant validity test

\begin{tabular}{lcccccc}
\hline \multirow{2}{*}{ Indicators } & \multicolumn{3}{c}{ SMEs } & & \multicolumn{3}{c}{ Small Business } \\
\cline { 2 - 7 } & $\mathrm{IK}$ & $\mathrm{PPAD}$ & $\mathrm{PSPC}$ & $\mathrm{IK}$ & $\mathrm{PPAD}$ & $\mathrm{PSPC}$ \\
\hline IK2 & 0.710 & 0.350 & 0.259 & 0.772 & 0.354 & 0.273 \\
IK3 & 0.818 & 0.536 & 0.395 & 0.862 & 0.453 & 0.323 \\
IK4 & 0.864 & 0.561 & 0.431 & 0.824 & 0.412 & 0.330 \\
IK5 & 0.727 & 0.554 & 0.441 & 0.697 & 0.394 & 0.160 \\
IK6 & 0.662 & 0.366 & 0.315 & 0.777 & 0.302 & 0.453 \\
PPAD1 & 0.306 & 0.732 & 0.448 & 0.390 & 0.688 & 0.493 \\
PPAD2 & 0.419 & 0.728 & 0.507 & 0.250 & 0.691 & 0.434 \\
PPAD4 & 0.350 & 0.651 & 0.407 & 0.367 & 0.742 & 0.362 \\
PPAD7 & 0.485 & 0.790 & 0.493 & 0.414 & 0.740 & 0.463 \\
PPAD8 & 0.449 & 0.656 & 0.406 & 0.356 & 0.700 & 0.429 \\
PPAD9 & 0.460 & 0.610 & 0.277 & 0.224 & 0.630 & 0.319 \\
PPAD12 & 0.646 & 0.791 & 0.539 & 0.518 & 0.681 & 0.375 \\
PSPC2 & 0.267 & 0.393 & 0.729 & 0.096 & 0.354 & 0.669 \\
PSPC4 & 0.467 & 0.438 & 0.715 & 0.248 & 0.556 & 0.855 \\
PSPC8 & 0.392 & 0.591 & 0.858 & 0.391 & 0.397 & 0.710 \\
\hline
\end{tabular}

Based on Figure 4, we can see that all indicators have a cross-loading greater value than other variables. Can conclude that the indicators used in this study have met the requirements of the discriminant validity test in preparing each dimension or the variable. Based on Figure 4 shows that each indicator in this study represents a latent variable in its block.

\section{c) Reliability Test}

In Table 4, the Cronbach's Alpha of each variable has a value greater than 0.6 , it can be concluded that the data has met the requirements of reliability test. Based on Table 4, the result shows that each indicator is stated to be consistent and reliable. The table above shows that the value composite reliability of each variable is greater than 0.7 , so it can be concluded that the indicators used in this study are reliable, namely accurate, consistent, and appropriate for measuring variables. 
Table 4. Composite Reliability and Cronbach's Alpha

\begin{tabular}{lcccc}
\hline \multirow{2}{*}{ Variable } & \multicolumn{2}{c}{ SMEs } & \multicolumn{2}{c}{ Small Business } \\
\cline { 2 - 5 } & $\begin{array}{c}\text { Cronbach's } \\
\text { Alpha }\end{array}$ & $\begin{array}{c}\text { Composite } \\
\text { Reliability }\end{array}$ & $\begin{array}{c}\text { Cronbach's } \\
\text { Alpha }\end{array}$ & $\begin{array}{c}\text { Composite } \\
\text { Reliability }\end{array}$ \\
\hline $\begin{array}{l}\text { Use of the Cashless } \\
\text { payment system }\end{array}$ & 0.657 & 0.813 & 0.611 & 0.791 \\
$\begin{array}{l}\text { Protection of Cashless } \\
\text { payment system users }\end{array}$ & 0.836 & 0.877 & 0.857 & 0.889 \\
Financial inclusion & 0.816 & 0.871 & 0.798 & 0.869 \\
\hline
\end{tabular}

\section{RESEARCH RESULTS}

\section{Hypothesis Testing}

Hypothesis Testing is done by looking at the t-statistic, with the testing criteria that fail to reject $\mathrm{H}_{0}$ and reject $\mathrm{H}_{1}$ if the t-statistic is $<1.96$.

Table 5. Hypothesis Testing

\begin{tabular}{ccccc}
\hline & Path analysis & t-statistic & T-table & Note \\
\hline \multirow{6}{*}{ SMEs } & PPAD -> IK & 11.56 & 1.96 & Accepted \\
& PSPC -> IK & 2.78 & 1.96 & Accepted \\
& PSPC -> PPAD & 18.31 & 1.96 & Accepted \\
\hline \multirow{3}{*}{ Small Business } & PPAD -> IK & 5.40 & 1.96 & Accepted \\
& PSPC -> IK & 0.60 & 1.96 & Rejected \\
& PSPC -> PPAD & 9.36 & 1.96 & Accepted \\
\hline
\end{tabular}

$\mathrm{H}_{1}$ : The use of the cashless payment system has a significant effect on the financial inclusion of MSEs in the Kediri Regency.

Based on the table above, it can be seen that MSEs with the influencing variable of the use of cashless payment systems on financial inclusion produce a t-statistic of $2.78>1.96$, which means reject $\mathrm{H}_{0}$. These results conclude that the use of cashless payment systems has a significant effect on MSEs financial inclusion in Kediri Regency.

Based on the table above, it can be seen that Small Businesses, with the influencing variable of the use of the cashless payment system on financial inclusion, produces a t-statistic of $0.60 \leq 1.96$, which means that it fails to reject $\mathrm{H} 0$. These results conclude that the cashless payment system has no significant effect on financial inclusion of MSEs in the Kediri Regency.

$\mathrm{H}_{2}$ : The use of a cashless payment system has a significant effect on protecting users of the cashless payment system.

Based on the table above, MSEs, with the influencing variable of the use of cashless payment systems on the protection of cashless payment system users, produce a t-statistic of 18.31>1.96, which means reject $\mathrm{H}_{0}$. These results conclude that the cashless payment system has a significant effect on the protection of cashless payment system users of UMK in Kediri Regency. Based on the table above, Small Businesses, with the influencing variable of the use of the cashless payment system on the protection of users of the cashless payment system, produce a t-statistic of 9.36> 1.96, which means reject $H_{0}$. These results conclude that the cashless payment system has a significant effect against the protection of cashless payment system users of MSEs in Kediri Regency.

$\mathrm{H}_{3}$ : Protection of payment system users cashless has a significant effect on the financial inclusion of MSEs in the Kediri Regency.

Based on the table above, MSEs, with the influencing variable of payment system user protection cashless on financial inclusion, produce a t-statistic of $11.56>1.96$, which means reject $\mathrm{H}_{0}$. These 
results conclude that the protection of cashless payment system users has a significant effect on financial inclusion of MSEs in Kediri Regency.

Based on the table above, Small Businesses, with the influencing variable of cashless payment system user protection on financial inclusion, produce a t-statistic of $5.40>1.96$, which means reject $\mathrm{H}_{0}$. These results conclude that the protection of cashless payment system users has a significant effect on the financial inclusion of MSEs in the Kediri Regency.

\section{DISCUSSION}

1. The Effect of cashless payment System Usage on Financial Inclusion

From the results of the research that has been done, it can be seen that the use of the cashless payment system has a significant effect on financial inclusion. From the research results, it can be seen that respondents use the cashless payment system for banking services $(58.9 \%)$. The number of documents required is small (61.5\%), and the minimum balance in savings accounts held by affordable financial institutions and other costs incurred affordable (54.25\%). The results of this study are consistent with research conducted by Must \& Ludewig (2010) in Brazil which shows that there is a significant influence between the use of a cashless payment system on financial inclusion in people who are urbanizing and the difficulty in sending money and expensive costs.

However, for small businesses, cashless payments do not have a significant effect on financial inclusion. It can be seen that the use of electronic money in small businesses only reached a level of $36.18 \%$, which was $7.35 \%$ lower than that of micro-businesses, that is $43.53 \%$. The relation indicates that small businesses are not taking advantage of technological developments, namely electronic money, because they feel comfortable making cash payments directly compared to cashless. The use of electronic money in small business transactions is also considered unprofitable for business owners due to additional costs such as shipping costs in large quantities which are influenced by the number of purchases of goods that are greater than that of micro-businesses. In addition to additional costs, there are nominal restrictions that cause the use of the cashless payment system for small businesses to have no significant effect on financial inclusion.

2. The Effect of Cashless Payment System Usage on Protection of Cashless Payment System Users.

From the research that has been done, it can be seen that the use of cashless payment systems has a significant effect on the protection of cashless payment system users. From the results of research that has been done, it can be seen that the use of the cashless payment system has a significant effect on the protection of users of the cashless payment system. The higher the use of the cashless payment system will increase the protection for users. The results of this study are supported by research conducted by Mazer (2016) in Kenya on payment cashless system users, which shows that the use of the cashless payment system has a significant effect on the protection of cashless payment system users.

3. The Effect of Cashless Payment System User Protection on Financial Inclusion

From the results of the research that has been done, it can be seen that the protection of cashless payment system users has a significant effect on financial inclusion. $63.25 \%$ of respondents stated that respondents believe providers can identify their users and avoid attacks from hackers. Respondents believe that providers cannot be wrong in processing transactions. This is also supported by the ease of stopping wrong cashless payment system transactions so that the protection of cashless payment system users has a significant effect on financial inclusion. The protection that users get will make users feel comfortable and feel protected, which will continue to use the cashless payment system so that it will increase financial inclusion. The results of this study are supported by previous research conducted by Mazer \& McKee (2017) conducted in America, which is seen from the track record of cashless payment system providers. This study shows that there is a significant influence between the protection of cashless payment system users on financial inclusion. Fraud awareness and prevention programs offered by providers to sensitize consumers to fraud trends can greatly increase cashless payment system services, thus increasing financial inclusion. 


\section{CONCLUSION AND FUTURE RESEARCH}

Based on the results of the analysis and discussion, there are two groups of conclusions that can be stated as follows:

1. The use of the cashless payment system has a significant effect on the financial inclusion of MSEs in the Kediri Regency, but in small businesses the use of cashless the payment system does not have a significant effect on financial inclusion in MSEs in Kediri Regency.

2. The use of the cashless payment system has a significant effect on the protection of users of the cashless payment system.

3. Protection of cashless payment system users has a significant effect on the financial inclusion of MSEs in the Kediri Regency.

In this research, of course, it has not yet reached perfection; therefore, researchers have suggestions that can be given in further research, as follows:

1. For MSEs, increase knowledge and understanding in using the cashless payment system so that MSEs can be careful in using the cashless payment system.

2. For cashless payment system providers, the results of this study show that there are still a few MSEs using electronic money; therefore, providers can provide education to MSEs.

3. For further researchers, this study has not focused on financial knowledge at MSEs, so that further research can discuss more deeply about financial knowledge at MSEs. In addition, additional researchers can also add information on the respondent's domicile and further emphasize the filling of the questionnaire regarding the use of the cashless payment system in business transactions on the questionnaire.

\section{REFERENCES}

Ardiansyah, G. (2020, April 28). Accounting teacher. Retrieved from Definition of financial literacy: https://guruakuntansi.co.id/literasi-keuangan/

Central Statistics Agency of East Java Province. (2019, October 10). Central Bureau of Statistics of East Java Province. Retrieved from Total Population by Provinces in Indonesia (thousand), 2014-2018: https://jatim.bps.go.id/statictable/2019/10/10/1715/jotal-penduduk-menurut-provinsi-di-indonesiathousand-2014-2018

Ervina. (2019, December 3). Talent Insight. Retrieved from the important role of MSMEs in the Economic Sector: https://www.talenta.co/blog/insight-talenta/peran-umkm/

Francisca, \& Malelak, M. I. (2020). Pengaruh corporate governance terhadap firm's debt pada perusahaan sektor industri barang konsumsi periode 2013-2018. International Journal of Financial and Investment Studies (IJFIS), 1(1), 30-41. https://doi.org/10.9744/ijfis.1.1.30-41.

Ghozali, I. (2014). Structural equation modeling. Semarang: Diponegoro University Publishing Agency.

Mazer.R, VK (2016, January 13). Finding 'win-win' in digitally delivered consumer credit. Retrieved from www.cgap.org/blog/finding-"win-win"-digitally delivered-consumer-credit

Mazer, R., \& McKee, K. (2017). Consumer protection in digital credit. CGAP, 1-24.

Minister of Law and Human Rights. (2008, July 10). Law No. 20 of 2008. Jakarta: State Institution of the Republic of Indonesia. Retrieved from Understanding MSMEs According to Experts and Laws That Should Be Understood as a Businessman: https://www.diadona.id/career/pengentuk-umkm-menurutpara-ahli-dan-undang-undang-yang-harus-dipaham -as-businessmen-200710y.html

Must, B., \& Ludewig, K. (2010). Mobile money: cell phone banking in developing countries. Policy Matter, 27-33.

OJK. (2013, August 6). POJK concerning Consumer Protection in the Financial Services Sector. Jakarta: OJK.

OJK. (2017, November). Jakarta, Jakarta, Indonesia.

Kediri City Government. (2019, July 18). Kediri City Government. Retrieved from TPAKD Kediri City welcomes the TPAKD award assessment team at the command center: https://kedirikota.go.id/p/berita/ 1019192/tpakd-kota-kediri-sambut-tim-penilai-tpakd-award-di-command- center

Kediri City Government. (2019, December 10). Kediri City Government. Retrieved from Kota Kediri to get TPAKD awards 2019 received by the Regional Secretary of Kediri City: https://kedirikota.go.id/p/berita/ 1019315/kota-kediri-raih-tpakd-awards-

Putri, WD (2020, February 1). lifepal. Retrieved from What is financial inclusion? this is the definition and benefits: https://lifepal.co.id/media/apa-itu-inklusi-keuangan-ini-pengentuk-dan- benefit/ 
Rangga. (2020, May 5). accounting teacher. Retrieved from Payment system: https://guruakuntansi.co.id/ sistem-pembayaran/

Rezkisari, I. (2018, April 12). Republika.co.id. Retrieved from BRI ATM fraud network in Kediri using spycams mode: https://nasional.republika.co.id/berita/p72uvg328/jaringan-penipuan-atm-bri-di-kediriuse-modus-spycams

Rintis Sejahtera. (2020, March 30). Prima. Retrieved from Indonesia towards a cashless society: https://www.jaringanprima.co.id/id/indonesia-menuju-cashless-society

Sugiyono. (2017). Quantitative, qualitative, and R\&D research methods. Bandung: Alfabeta, cv.

Sulaiman, F. (2019, March 21). Economic News. Retrieved from What is financial literacy ?: https://www.wartaekonomi.co.id/read220393/apa-itu-literasi-keuangan

Tee, H.-H., \& Ong, H.-B. (2016, April 7). Financial Innovation. Cashless payment and economic growth.

Valant, J. (2015). Consumer protection aspects of mobile payments. Europe: European Parliamentary Research Service.

Wahono, H. K., \& Pertiwi, D. (2020). Pengaruh Financial Literacy, Materialism, Compulsive Buying Terhadap Propensity to Indebtedness. International Journal of Financial and Investment Studies (IJFIS), 1(1), 114. https://doi.org/10.9744/ijfis.1.1.1-14

World Bank. (2018, October 2). the world bank. Retrieved from financial inclusion: https://www.worldbank. org/en/topic/financialinclusion/overview 